\title{
PENGARUH TIPE FERMENTOR DAN LEVEL PEMBERIAN FESES PUYUH TERHADAP PRODUKSI DAN KUALITAS TELUR PUYUH
}

\author{
Hermy Puspita Sari ${ }^{1)}$, Urip Santoso ${ }^{2)}$, Heri Dwi Putranto ${ }^{2)}$ \\ 1) Balai Penyuluhan Pertanian Kecamatan Teluk Segara dan Kecamatan Sungai Serut \\ ${ }^{2)}$ Jurusan Peternakan Fakultas Pertanian UNIB
}

\begin{abstract}
ABSTRAK
Feses yang dihasilkan dari usaha peternakan puyuh berupa feses puyuh belum termanfaatkan secara maksimal sehingga masih berdampak kepada pencemaran lingkungan seperti pencemaran pada air, udara dan tanah. Kandungan protein kasar yang rendah dan serat kasar yang cukup tinggi ini merupakan faktor pembatas penggunaan feses puyuh sebagai pakan ternak sehingga perlu pengolahan agar penggunaannya optimal. Salah satu upaya yang dapat dilakukan untuk meningkatkan penggunaan feses puyuh dalam ransum, yaitu memanfaatkan Teknologi Fermentasi. Mikroorganisme yang digunakan dalam fermentasi adalah mikroorganisme yang ada di Em4, ragi tempe dan ragi tape. Tujuan Peneltian mengevaluasi pengaruh tipe fermentor terhadap produksi dan kualitas telur puyuh. Mengevaluasi pengaruh level pemberian feses puyuh fermentasi terhadap produksi dan kualitas telur puyuh Mengevaluasi interaksi antara tipe fermentor dengan level pemberian feses puyuh fermentasi terhadap produksi dan kualitas telur puyuh. Bahan penelitian yang digunakan adalah puyuh betina awal produksi sebanyak 360 ekor. Rancangan yang digunakan adalah rancangan acak lengkap (RAL) dengan 2 faktor yaitu faktor pertama level pemberian feses (Faktor $\mathrm{A}=10 \%, 15 \%$ dan 20\%) dan faktor kedua tipe fermentor (Faktor B = EM4, Ragi Tempe dan Ragi Tape). Hasil penelitian menunjukkan bahwa terdapat interksi antara Faktor A dan Faktor B terhadap konsumsi ransum, produksi massa telur, konversi ransum $(\mathrm{P}<0,005)$ dan produksi telur $(\mathrm{P}<0,001$. Tidak terdapat interaksi antara Faktor A dan Faktor B terhadap berat telur, berat yolk, kecerahan yolk dan tebal kerabang $(\mathrm{P}>0,05)$. Kesimpulan penelitian bahwa nteraksi antara tipe fermentor dan level pemberian feses terbaik adalah tipe fermentor EM4 dengan level pemberian feses puyuh sebesar $10 \%$.
\end{abstract}

Kata Kunci: Feses, Puyuh, Teknologi Fermentasi, Produksi Telur Dan Kualitas Telur

\section{PENDAHULUAN}

Feses yang dihasilkan dari usaha peternakan puyuh berupa feses puyuh belum termanfaatkan secara maksimal sehingga masih berdampak kepada pencemaran lingkungan seperti pencemaran pada air, udara dan tanah.

Feses ayam, sapi maupun puyuh memiliki keunggulan tersendiri dalam aspek kemudahan untuk memperoleh, harga serta ketersedian feses. Feses ayam dan feses sapi merupakan jenis feses yang umum digunakan dalam bidang pertanian, sehingga penyediannya mudah diperoleh. Feses puyuh belum umum digunakan tetapi hal tersebut menyebabkan ketersediaan terjamin karena tidak perlu bersaing dengan pengguna feses untuk kepeluan pertanian. Selain itu, dalam segi 
harga, feses ayam murni memilki harga yang lebih mahal dibandingkan dengan feses puyuh. Feses puyuh segar memiliki kandungan protein kasar sebesar 17,40\% serat kasar 23,30\%, lemak kasar 2,80\%, abu 25,90\% dan BETN 30,58\% (Indra, 2014).

Kandungan protein kasar yang rendah dan serat kasar yang cukup tinggi ini merupakan faktor pembatas penggunaan feses puyuh sebagai pakan ternak sehingga perlu pengolahan agar penggunaannya optimal. Salah satu upaya yang dapat dilakukan untuk meningkatkan penggunaan feses puyuh dalam ransum, yaitu memanfaatkan Teknologi Fermentasi. Pemakaian produk fermentasi kotoran ayam sebesar 5\% sampai $20 \%$ dalam ransum ayam broiler menunjukan peningkatan pada konsumsi ransum

\section{METODE PENELITIAN}

\section{Tempat dan Waktu Pelaksanaan}

Telah dilakukan di rumah peneliti yang beralamatkan Jalan Dharma Wanita RT 2 RW 4 Kelurahan Bentiring Kecamatan Maura Bangkahulu Kota Bengkulu. Telah dilaksanakan pada bulan November-Desember 2017.

\section{Alat dan Bahan}

Bahan yang digunakan adalah puyuh sebanyak 360 ekor yang berumur 8 minggu, feses puyuh, EM4, ragi tempe, ragi tape, jagung, dedak, konsentrat puyuh, gula,air, mineral dan top mix.

\section{Tahapan Penelitian}

\section{a. Membuat feses puyuh fermentasi dengan EM4}

Cara pembuatan adalah sebagai berikut: Bahan yang digunakan adalah 10 $\mathrm{kg}$ feses puyuh kering, $240 \mathrm{ml}$ EM4, 240 $\mathrm{ml}$ gula pasir, dan 2 liter air. Cara membuat yaitu Siapkan larutan dengan campuran air 2 liter $(2000 \mathrm{ml})$ tambahkan $240 \mathrm{ml} \mathrm{EM} 4$ dan $240 \mathrm{ml} / 24$ sdm gula pasir lalu aduk rata. Selanjutnya
(2880,64 gr/ekor-2978,75 gr/ekor) dan konversi ransum $(1,61-1,66)$ (Wattiheluw et al., 2014).

Berdasarkan uraian di atas maka sangat diperlukan untuk dilakukan penelitian mengenai pengaruh penggunaan tipe fermentor dan level pemberian feses puyuh fermentasi sebagai pakan puyuh terhadap produksi dan kualitas telur puyuh.

\section{Tujuan Peneltian}

1. Mengevaluasi pengaruh tipe fermentor terhadap produksi dan kualitas telur puyuh. 2. Mengevaluasi pengaruh level pemberian feses puyuh fermentasi terhadap produksi dan kualitas telur puyuh 3. Mengevaluasi interaksi antara tipe fermentor dengan level pemberian feses puyuh fermentasi terhadap produksi dan kualitas telur puyuh.

larutan campuran air, EM4 dan gula di inkubasikan selama 72 jam dalam keadaan anaerob. Setelah 72 jam siapkan feses puyuh $10 \mathrm{~kg}$ diatas plastik terpal hitam. Siram larutan ke feses puyuh sedikit demi sedikit sambil dicampur rata sampai kadar air $60 \%$ yang ditandai dengan apabila dikepal bentuknya tetap konsisten dan sudah dapat dibentuk. Lalu peram dalam plastik terpal hitam selama 4 hari. Setiap dua hari periksa apakah terjadi fermentasi. Fermentasi ditandai dengan terjadinya peningkatan suhu yaitu $40-60^{\circ} \mathrm{C}$. Jika suhu terlalu tinggi maka lakukan pembalikan, lalu tutup kembali. Setelah 4 hari fermentasi selesai, ditandai dengan tidak terjadinya peningkatan suhu (suhu stabil), tidak ada bau busuk. Jemur feses puyuh yang sudah difermentasi sampai kering. Giling feses yang sudah kering sehingga menjadi tepung feses puyuh (Santoso et al., 2004).

\section{b. Membuat fermentasi dengan menggunakan Ragi Tempe}

Bahan yang digunakan adalah Bahan tepung feses yang telah difermentasi, Air secukupnya, 2 sdm ragi tempe bubuk dan 
Daun pisang. Cara membuat adalah Campur air dan feses puyuh hingga rata, sampai kadar air sekitar $60 \%$ yang ditandai apabila digumpal lalu dilepas campuran tetap konsisten bentuknya. Kukus sekitar, 1 jam (mendidih), lalu angkat dan dikeringanginkan (sekitar 1,5 jam). Setelah dingin, Taburkan ragi sedikit demi sedikit sambil diaduk rata. (setiap $10 \mathrm{~kg}$ bahan tambahkan 2 sdm ragi. Masukkan kedalam nyiru yang terlebih dahulu dialasi dengan daun pisang, lalu tutup dengan plastik. Peram selama 3 hari (Tempe feses jadi ditandai dengan tumbuhnya miselium warna keputihan). Feses fermentasi dengan ragi tempe telah siap digunakan.

\section{c. Membuat fermentasi dengan menggunakan Ragi Tape}

Fermentasi feses Puyuh dengan ragi tape adalah suatu bahan pakan yang dibuat dari feses puyuh yang telah dijemur sampai kering kemudian digiling menjadi tepung feses puyuh. Cara pembuatan adalah sebagai berikut.

Bahan yang digunakan adalah Bahan tepung feses yang telah difermentasi, Air secukupnya, 2 sdm ragi tape bubuk dan Daun pisang. Cara membuat yaitu Campur air dan feses puyuh hingga rata, sampai kadar air sekitar $60 \%$ yang ditandai apabila digumpal lalu dilepas campuran bentuknya tetap konsisten. Kukus sekitar, 1 jam (mendidih), lalu angkat dan dikeringanginkan (sekitar 1,5 jam). Setelah dingin, Taburkan ragi sedikit demi sedikit sambil diaduk rata, (setiap $10 \mathrm{~kg}$ bahan tambahkan $2 \mathrm{sdm}$ ragi. Masukkan kedalam nyiru yang terlebih dahulu dialasi dengan daun pisang, lalu tutup dengan plastik. Peram selama 3 hari (Tape feses jadi ditandai dengan tumbuhnya miselium warna keputihan). Feses fermentasi dengan ragi tape telah siap digunakan.

\section{Rancangan penelitian}

Rancangan yang digunakan adalah rancangan acak lengkap (RAL ) dengan 2 Berat Yolk faktor (Tabel 3) yaitu faktor pertama level pemberian feses (faktor $\mathrm{A}=10 \%, 15 \%$ dan $20 \%$ ) dan faktor kedua produk feses fermentasi (faktor B = Tidak fermentasi, EM4, Ragi Tempe dan Ragi Tape). Percobaan ini akan menggunakan puyuh petelur fase produksi 8 minggu sebanyak 360 ekor. Setiap perlakuan terdiri dari 4 ulangan dan setiap ulangan terdiri dari 10 ekor puyuh yang di tempatkan secara acak pada kandang individual (kandang battray).

\section{Variabel yang Diamati \\ Konsumsi Ransum}

Konsumsi ransum dihitung berdasarkan jumlah ransum yang diberikan setiap minggu (gram/ekor/hari) kemudian dikurangi dengan sisa ransum pada akhir minggu (gram/ekor/hari) (Rasyaf, 2006).

\section{Produksi Telur}

Produksi telur (butir/ekor/minggu) diketahui dengan menghitung jumlah telur yang dihasilkan selama penelitian, dicatat setiap hari (Rasyaf, 2006).

\section{Produksi Massa Telur}

Produksi masaa telur diperoleh dengan cara menghitung produksi telur harian/quail day selama satu bulan dikalikan berat telur rata-rata sebutir telur yang dihasilkan dalam bulan tersebut (Latif et al., 2011).

\section{Konversi Ransum}

Latif et al. (2011) konversi ransum dihitung dengan cara membagi konsumsi ransum dengan produksi massa telur.

\section{Berat Telur}

Menurut Rasyaf (2006), berat rata-rata perbutir berat telur (gram/butir) dihitung berdasarkan total berat telur (gram/butir) dibagi dengan jumlah butir telur yang dihasilkan.

Badan Standar Nasional Indonesia (2008) menjelaskan perhitungan untuk 
mengetahui Indeks Kuning Telur (IKT) atau Indeks Yolk dengan menggunakan rumus $\mathrm{IKT}=$ tinggi kuning telur $(\mathrm{mm})$ diameter kuning telur $(\mathrm{mm})$ menggunakan mikrometer scrup.

\section{Kecerahan Yolk}

Menurut Kurtini et al. (2014) kualitas warna yolk ditentukan secara visual, yaitu membandingkan dengan berbagai warna standar dari yolk colour fan.

\section{Tebal kerabang}

Pengukuran tebal kerabang telur dilakukan pada bagian ujung tumpul, tengah (ekuator), dan ujung lancip telur kemudian dibuat rata-rata. Tebal kerabang dihitung dengan menggunakan jangka sorong (Herni, 2014).

\section{Analisis Data}

Hasil percobaan di analisis dengan ANOVA dan jika menunjukkan berbeda nyata maka diuji dengan Duncan's Multiple Range Test (DMRT).

\section{Tabel 1. Komposisi Nutrisi Bahan Penyusun Ransum}

\begin{tabular}{|c|c|c|c|c|c|c|c|c|}
\hline Bahan pakan & $\begin{array}{l}\text { Protei } \\
(\%)\end{array}$ & $\begin{array}{l}\text { Energi } \\
(\mathbf{k k a l} / \mathbf{k}\end{array}$ & $\begin{array}{l}\text { SK } \\
(\%)\end{array}$ & $\begin{array}{c}\text { Lemakk } \\
\qquad(\%)\end{array}$ & $\begin{array}{c}\mathrm{Ca} \\
(\%)\end{array}$ & $\begin{array}{l}P \\
(\%)\end{array}$ & Air & Abu \\
\hline 1. Jagung giling & 8.55 & 3105.66 & 2.42 & 2.97 & 0.37 & 0.44 & 0 & 0 \\
\hline $\begin{array}{l}\text { 2. Feses puyuh fermen- } \\
\text { tasi dengan EM4 } *\end{array}$ & $\begin{array}{c}13.6 \\
5\end{array}$ & 11983 & 22 & 0.47 & 12 & 1.85 & 10.11 & 38.52 \\
\hline $\begin{array}{l}\text { 3. Feses puyuh fermen- } \\
\text { tasi dengan ragi tem- } \\
\text { pe* }^{*}\end{array}$ & $\begin{array}{c}10.0 \\
5\end{array}$ & 1221.4 & 20.6 & 0.54 & 12.23 & 1.86 & 7.61 & 41.87 \\
\hline $\begin{array}{l}\text { 4. Feses puyuh fermen- } \\
\text { tasi dengan ragi tape } \\
*\end{array}$ & $\begin{array}{c}12.2 \\
0\end{array}$ & 1217.6 & 21.42 & 0.55 & 12.76 & 1.82 & 7.41 & 41.38 \\
\hline 5. Dedak Halus & $\begin{array}{c}10.4 \\
5\end{array}$ & 1856.49 & 19.34 & 9.78 & 0.92 & 0.29 & 0 & 0 \\
\hline 6. Mineral & 0 & 0 & 0 & 0 & 32 & 10 & 0 & 0 \\
\hline 7. Top Mix & 0 & 0 & 0 & 0 & 0 & 0 & 0 & 0 \\
\hline
\end{tabular}

Sumber : Fenita (2005)

* Hasil analisis politeknik pertanian negeri payakumbuh, SUMBAR 2017 


\section{HASIL DAN PEMBAHASAN}

\section{Pengaruh fermentor dan level}

Tabel 2. Pengaruh tipe fermentor terhadap konsumsi ransum, produksi telur, produksi massa telur dan konversi ransum.

\begin{tabular}{|c|c|c|c|c|c|c|}
\hline \multirow[t]{2}{*}{ Parameter } & & \multicolumn{3}{|c|}{ Tipe fermentor } & \multirow[t]{2}{*}{ SD } & \multirow[t]{2}{*}{$P$} \\
\hline & & B1 & B2 & B3 & & \\
\hline $\begin{array}{l}\text { Konsumsi } \\
\text { (gr/ekor) }\end{array}$ & ransum & $1631,0^{\mathrm{b}}$ & $1573,6^{\mathrm{a}}$ & $1594,6^{\mathrm{a}}$ & 33,1 & $0,005 * *$ \\
\hline $\begin{array}{l}\text { Produksi } \\
\text { (butir/ekor) }\end{array}$ & telur & $29^{c}$ & $25^{\mathrm{b}}$ & $19^{\mathrm{a}}$ & 4,15 & $0,000 * *$ \\
\hline $\begin{array}{l}\text { Produksi } \\
\text { (gr/ekor) }\end{array}$ & massa & $321,19^{c}$ & $269,44^{b}$ & $215,49^{\mathrm{a}}$ & 46,8 & $0,000 * *$ \\
\hline Konversi ra & sum & $4,99^{\mathrm{a}}$ & $6,01^{b}$ & $7,55^{\mathrm{c}}$ & 1,12 & $0,000 * *$ \\
\hline
\end{tabular}

Tabel 3 Pengaruh tipe fermentor pada berat telur berat yolk kecerahan yolk dan tebal kerabang selama penelitian

\begin{tabular}{|c|c|c|c|c|c|}
\hline \multirow[t]{2}{*}{ Parameter } & \multicolumn{3}{|c|}{ Fermentor } & \multirow[t]{2}{*}{ SD } & \multirow[t]{2}{*}{$\mathrm{P}$} \\
\hline & B1 & B2 & B3 & & \\
\hline Berat Telur & 9,0 & 8,6 & 8,8 & 0,35 & 0,245 \\
\hline Berat yolk & 3,4 & 3,5 & 3,6 & 0,27 & 0,667 \\
\hline Kecerahan Yolk & $6,7^{\mathrm{b}}$ & $6,5^{\mathrm{b}}$ & $4,8^{b}$ & 0,95 & $0,000 * *$ \\
\hline Tebal kerabang & 0,228 & 0,223 & 0,22 & 0,006 & 0,071 \\
\hline
\end{tabular}

Tabel 4.Pengaruh level feses terhadap konsumsi ransum, produksi telur, produksi massa telur dan konversi ransum selama penelitian

\begin{tabular}{|c|c|c|c|c|c|c|}
\hline \multirow[t]{2}{*}{ Parameter } & & \multicolumn{3}{|c|}{ Level } & \multirow[t]{2}{*}{ SD } & \multirow[t]{2}{*}{$\mathrm{P}$} \\
\hline & & $10 \%$ & $15 \%$ & $20 \%$ & & \\
\hline $\begin{array}{l}\text { Konsumsi } \\
\text { (gr/ekor) }\end{array}$ & ransum & $1607,1^{\mathrm{b}}$ & $1616,1^{\mathrm{b}}$ & $1576,0^{\mathrm{a}}$ & 28,44 & $0,048^{*}$ \\
\hline $\begin{array}{l}\text { Produksi } \\
\text { (butir/ekor) }\end{array}$ & telur & $27^{\mathrm{c}}$ & $24^{\mathrm{b}}$ & $22^{\mathrm{a}}$ & 2,29 & $0,000 * *$ \\
\hline $\begin{array}{l}\text { Produksi } \\
\text { (gr/ekor) }\end{array}$ & massa & $308,26^{\mathrm{C}}$ & $263,99^{\mathrm{b}}$ & $233,8^{\mathrm{a}}$ & 33,5 & 0,000 ** \\
\hline \multicolumn{2}{|c|}{ Konversi ransum } & $5,42^{\mathrm{a}}$ & $6,21^{\mathrm{b}}$ & $6,9^{\mathrm{c}}$ & 0,70 & $0,000 * *$ \\
\hline
\end{tabular}


Tabel 5. Pengaruh pemberian level pada berat telur, berat yolk, kecerahan yolk dan tebal kerabang selama penelitian

\begin{tabular}{|c|c|c|c|c|c|}
\hline \multirow[t]{2}{*}{ Parameter } & \multicolumn{3}{|c|}{ Level } & \multirow[t]{2}{*}{ SD } & \multirow[t]{2}{*}{$\mathrm{P}$} \\
\hline & $10 \%$ & $15 \%$ & $20 \%$ & & \\
\hline Berat Telur & 9,1 & 8,7 & 8,5 & 0,42 & 0,059 \\
\hline Berat yolk & 3,5 & 3,5 & 3,5 & 0,24 & 0,987 \\
\hline Kecerahan Yolk & 6,0 & 6,2 & 5,9 & 0,52 & 0,615 \\
\hline Tebal kerabang & 0,227 & 0,223 & 0,220 & 0,005 & 0,171 \\
\hline \multicolumn{6}{|l|}{ eterangan: } \\
\hline $1=$ Pemberian lev & & & \multicolumn{3}{|c|}{$\mathrm{B} 1$ = Tipe Fermentasi dgn EM4 } \\
\hline $2=$ Pemberian lev & & & \multicolumn{3}{|c|}{$\mathrm{B} 2$ = Tipe Fermentasi dengan ragi tempe } \\
\hline $3=$ Pemberian lev & & & \multicolumn{3}{|c|}{ B3 = Tipe Fermentasi dengan ragi tape } \\
\hline$=$ Berpengaruh $\mathrm{r}$ & $\mathrm{P}<0,005)$ & & $* *=\mathrm{Be}$ & h sanga & $<0,001)$ \\
\hline
\end{tabular}

\section{a.Pengaruh fermentor terhadap} konsumsi ransum, produksi massa telur, produksi telur dan konversi ransum

Hasil sidik ragam (ANOVA) menujukkan bahwa tipe fermentor berpengaruh sangat nyata terhadap konsumsi ransum, produksi telur, produksi massa telur dan konversi ransum $(\mathrm{P}<0,01)$. Hasil uji DMRT menunjukkan bahwa konsumsi ransum pada puyuh yang diberi feses yang difermentasi dengan ragi tape dan ragi tempe lebih rendah dari EM4 $(\mathrm{P}<0,01)$. Hal ini karena penambahan probiotik Lactobacillus dalam ransum dapat menyebabkan peningkatan aktivitas mikroba non patogen di dalam saluran pencernaan burung puyuh (Sjofjan et al., 2015).

Hasil uji DMRT juga memperlihatkan bahwa produksi telur yang diberi feses yang difermentasi dengan ragi tape dan ragi tempe lebih rendah dari EM4, sedangkan ragi tape lebih rendah dari ragi tempe $(\mathrm{P}<0,01)$. Hal ini diduga dengan penambahan mikroba Lactobacillus lebih baik dari penambahan mikroba Rhizopus oligosporus dan Saccharomyces. Lactobacillus merupakan mikrobia alami yang ada dalam saluran pencernaan.

Hasil Uji DMRT menjelaskan bahwa produksi massa telur pada puyuh yang diberi feses difermentasi dengan ragi tape dan ragi tempe lebih rendah dari EM4 $(\mathrm{P}<0,01)$ sedangkan feses yang diberi ragi tape lebih rendah dari ragi tempe. Hal ini diduga dengan penambahan mikroba Lactobacillus lebih baik dari penambahan mikroba Rhizopus oligosporus dan Saccharomyces.

Hasil Uji DMRT memperlihatkan bahwa konversi ransum pada puyuh yang diberi feses difermentasi dengan EM4 dan ragi tempe lebih rendah dari ragi tape $(\mathrm{P}<0,01)$. Hal ini diduga dengan penambahan mikroba Lactobacillus lebih baik dari penambahan mikroba Rhizopus oligosporus dan Saccharomyces. Hal ini menunjukkan bahwa Lactobacillus yang ada EM4 di duga mampu menciptakan keseimbangan mikrobia dalam saluran pencernaan dibanding mikroba lain.

\section{b. Pengaruh level terhadap konsumsi ransum, produksi massa telur, produksi telur dan konversi ransum}

Hasil sidik ragam (ANOVA) menujukkan bahwa level pemberian feses fermentasi berpengaruh sangat nyata terhadap produksi telur, produksi massa telur dan konversi ransum $(\mathrm{P}<0,01)$ dan berpengaruh nyata terhadap konsumsi ransum $(\mathrm{P}<0,05)$. Hasil uji DMRT menunjukkan bahwa konsumsi ransum pada puyuh yang diberi level feses sebesar $20 \%$ lebih rendah dari level $10 \%$ dan $15 \%$ $(\mathrm{P}<0,05)$. Ini berarti level pemberian sebesar $10 \%$ lebih disukai puyuh petelur, 
hal ini diduga berkaitan dengan palatabilitas pakan dimana menurut Latif et al. (2011) produk fermentasi mempunyai flavour yang lebih disukai dan memiliki beberapa vitamin (B1, B2 dan B12) sehingga lebih palatabel (disukai) bila dibandingkan bahan asalnya.

Hasil Uji DMRT memperlihatkan bahwa produksi telur pada puyuh yang diberi level feses sebesar $20 \%$ lebih rendah dari level $10 \%$ dan $15 \% \quad(\mathrm{P}<0,01)$. pemberian level sebesar $20 \%$ menunjukkan nilai produksi telur terendah diduga disebabkan oleh konsumsi ransum yang cenderung menurun pada level 20\%. Astuti dan Suwiningsih (2010), menyatakan bahwa indikator penentu produktifitas telur banyak dipengaruhi oleh kandungan nutrisi pakan, konsumsi pakan, dan umur. Hasil uji DMRT menjelaskan bahwa produksi massa telur pada puyuh yang diberi level feses sebesar $20 \%$ lebih rendah dari level $10 \%$ dan $15 \% \quad(\mathrm{P}<0,01)$. Ini disebabkan produksi telur dan berat telur memilki nilai yang paling tinggi pada level 10\% karena produksi massa telur merupakan hasil kali produksi telur dan berat telur.

Hasil uji DMRT menujukkan bahwa konversi ransum pada puyuh yang diberi feses sebesar $10 \%$ lebih rendah dari level $15 \%$ dan $20 \%(\mathrm{P}<0,01)$. Konversi ransum akan berbanding lurus dengan tingkat konsumsi ransum. Penambahan feses fermentasi dengan taraf yang lebih tinggi (20\%) akan meningkatkan konsumsi ransum. Hal ini diduga karena kandungan feses fermentasi dapat mempercepat pengosongan lambung sehingga laju ransum tinggi dan ternak mudah lapar (Islami, 2011).

\section{c. Pengaruh fermentor terhadap berat telur, berat yolk, kecerahan yolk dan tebal kerabang}

Hasil sidik ragam (ANOVA) menunjukkan bahwa tipe fermentor bepengaruh tidak nyata terhadap berat yolk, berat telur dan tebal kerabang $(\mathrm{P}>0,05)$ tetapi berpengaruh sangat nyata terhadap kecerahan yolk $(\mathrm{P}<0,01)$. Tabel 3. dapat dijelaskan bahwa penggunaan tipe fermentasi dapat digunakan pada berat telur. Tidak berpengaruhnya tipe fermentor terhadap berat telur diduga mikroba Lactobacillus, Rhizopus oligosporus dan Saccharomyces tidak mampu meningkatkan daya cerna dan mengekresikan enzim protease dan lipase.

Tabel 3. dijelaskan bahwa penggunaan tipe fermentor dapat digunakan pada berat yolk. Tidak berpengaruhnya level pemberian feses fermentasi terhadap berat telur diduga karena mikroba Lactobacillus, Rhizopus oligosporus dan Saccharomyces tidak dapat meningkatkan berat yolk karena penyerapan protein dan lemak dalam proses pembentukan yolk terhambat oleh lendir yang dihasilkan sel goblet di dalam saluran pencernaan.

Hasil uji DMRT menunjukkan bahwa kecerahan yolk pada puyuh yang feses difermentasi dengan ragi tape dan ragi tempe lebih rendah dari EM4 $(\mathrm{P}<0,01)$. Hal ini diduga disebabkan kandungan $\beta$ karoten yang tinggi pada perlakuan tersebut. Semakin tinggi penggunaan tipe fermentasi dapat mengurangi penggunaan jagung, maka diduga kandungan $B$ karoten semakin meningkat sehingga intesitas kecerahan yolk yang dihasilkan lebih tinggi, kandungan $\beta$ karoten pada jagung sebesar (33,00 mg/kg) (Latif et al., 2011). Tabel 3. menjelaskan bahwa penggunaan tipe fermentasi dapat digunakan terhadap tebal kerabang namun tidak memberikan pengaruh level pemberian feses fermentasi terhadap tebal kerabang. Kerabang telur adalah suatu struktur mineral yang tersusun terutama dari $\mathrm{CaCO} 3$. Kerabang telur terdiri dari dua bagian yaitu kerabang tipis (membran) dan kerabang telur keras. Pada penelitian ini jenis dan umur puyuh, jenis pakan, konsumsi pakan, serta penggunaan cahaya penerangan yang digunakan adalah 
sama sehingga rataan tebal kerabang telur puyuh yang diperoleh berkisar antara 0,220 $\mathrm{mm}-0,228 \mathrm{~mm}$ sehingga perlakuan tidak berbeda nyata.

\section{d. Pengaruh level terhadap berat telur, berat yolk, kecerahan yolk dan tebal kerabang}

Hasil sidik ragam (ANOVA) menunjukkan bahwa level pemberian feses fermentasi bepengaruh tidak nyata terhadap berat telur, berat yolk, kecerahan yolk dan tebal kerabang $(\mathrm{P}>0,05)$. Tabel 4 . dapat dijelaskan bahwa penggunaan tipe fermentasi dapat digunakan sampai level $20 \%$ pada berat telur. Pada penelitian ini menggunakan kandungan protein sebesar $21 \%$ dengan umur 8 minggu menghasilkan berat telur yang lebih rendah sebesar 9,1 dari peneitian Eishu et al. (2005) yaitu pada burung puyuh yang berumur 8-9 minggu yang diberi pakan dengan kandungan protein $22 \%$ berat telurnya 9,2 g. Sedangkan untuk Standar berat telur burung puyuh berkisar antara 9,30 g - 9,78 g/butir (Sihombing et al., 2006).

Analisis sidik ragam menunjukkan bahwa berat kuning telur tidak dipengaruhi oleh level pemberian feses ransum puyuh. Berat yolk yang tidak berbeda dari penelitian ini disebabkan karena pakan yang dikonsumsi sama dengan tingkat konsumsi yang sama. Dengan demikian,asupan asam amino terutama metionin dan asam lemak linoleat daripakan yang diberikan juga tidak berbeda (Leeson dan Summer, 1991). Tabel 4. dapat dijelaskan bahwa penggunaan tipe fermentasi dapat digunakan sampai level $20 \%$ pada kecerahan yolk. Pada penelitian ini, kecerahan yolk diukur dengan menggunakan Yolk Colour Fan. Pigmen yang berpengaruh terhadap kecerahan yolk adalah pigmen karoten (Yuwanta, 2004). Kecerahan yolk telur pada penelitian ini berkisar antara 5,9-6,2 dengan rataan sebesar 3,9. Peningkatan level pemberian feses fermentasi tidak berpengaruh terhadap warna kuning telur. Tabel 4. dapat dijelaskan bahwa penggunaan tipe fermentasi dapat digunakan sampai level $20 \%$ pada tebal kerabang. Kualitas kerabang telur terutama ditentukan oleh tebal dan struktur kulit telur. Tebal kerabang telur pada penelitian ini berkisar antara 0,227-0,220. Tebal kerabang telur puyuh tidak dipengaruhi oleh level pemberian feses fermentasi puyuh $(\mathrm{P}>0,005)$

\section{2 a. Interaksi antara fermentor dan level terhadap konsumsi ransum, produksi telur, produksi massa telur dan konversi ransum}

Hasil sidik ragam (ANOVA) menujukkan bahwa interaksi antara tipe fermentasi dan level pemberian bepengaruh nyata $(\mathrm{P}<0,05)$ terhadap produksi massa telur, konsumsi ransum dan konversi ransum dan berpengaruh sangat nyata $(\mathrm{P}<0,01)$ terhadap produksi telur

Hasil uji DMRT menunjukkan (Tabel 6) bahwa A3B2 mempunyai konsumsi ransum yang lebih banyak dengan perlakuannya. Feses yang difermentasi dengan ragi tempe sebanyak $20 \%$ mempunyai konsumsi ransum terbanyak hal ini disebabkan ragi tempe lebih palatabel, sesuai dengan pendapat Amrullah (2002) yang menyatakan bahwa palatabilitas menentukan banyaknya makanan yang dikonsumsi

Hasil uji DMRT menyajikan bahwa produksi telur terbaik terdapat pada perlakuan A1B1, A2B1 dan A1B2 hal ini diduga dengan adanya penambahan probiotik pada EM4 dan ragi tempe dapat meningkatkan penyerapan makanan ke dalam tubuh ternak. 
Interaksi antara Fermentor dengan Level

Tabel 6. Pengaruh interaksi antara tipe fermentor dengan level terhadap konsumsi ransum, produksi telur, produksi massa telur, dan konversi ransum selama penelitian

\begin{tabular}{|c|c|c|c|c|c|c|c|c|c|c|c|}
\hline \multirow{2}{*}{ Parameter } & \multicolumn{9}{|c|}{ Perlakuan } & \multirow[t]{2}{*}{ SD } & \multirow[t]{2}{*}{$\mathrm{P}$} \\
\hline & A1B1 & $\mathrm{A} 2 \mathrm{~B} 1$ & A3B1 & $\mathrm{A} 1 \mathrm{~B} 2$ & $\mathrm{~A} 2 \mathrm{~B} 2$ & A3B 2 & A1B3 & A2B3 & A3B3 & & \\
\hline $\begin{array}{l}\text { Konsumsi } \\
\text { Ransum (g/ekor) }\end{array}$ & $1618,3^{\mathrm{a}}$ & $1648,1^{a}$ & $1626,5^{\mathrm{a}}$ & $1627,4^{\mathrm{a}}$ & $1573,5^{\mathrm{a}}$ & $2022,2^{\mathrm{b}}$ & $1575,5^{\mathrm{a}}$ & $1636^{\mathrm{a}}$ & $1572,6^{\mathrm{a}}$ & 140,4 & 0,022 \\
\hline $\begin{array}{l}\text { Produksi } \\
\text { Telur (butir/ekor) }\end{array}$ & $30^{\mathrm{e}}$ & $28^{\mathrm{de}}$ & $27^{\mathrm{d}}$ & $30^{\mathrm{e}}$ & $24^{\mathrm{c}}$ & $20^{\mathrm{b}}$ & $20^{\mathrm{ab}}$ & $21^{\mathrm{b}}$ & $17^{\mathrm{a}}$ & 4,9 & 0,000 \\
\hline $\begin{array}{l}\text { Produksi Massa } \\
\text { Telur (g/ekor) }\end{array}$ & $346,2^{\mathrm{e}}$ & $315,5^{\mathrm{de}}$ & $301,8^{\mathrm{d}}$ & $342,4^{\mathrm{de}}$ & $254,2^{\mathrm{c}}$ & $211,6^{\mathrm{ab}}$ & $236,1^{b c}$ & $222,2^{a b c}$ & $185,2^{\mathrm{a}}$ & 59,5 & 0,014 \\
\hline Konversi Ransum & $4,6^{\mathrm{a}}$ & $5,2^{\mathrm{a}}$ & $5,1^{\mathrm{a}}$ & $4,7^{\mathrm{a}}$ & $6,1^{b}$ & $7,1^{\mathrm{c}}$ & $6,8^{\mathrm{cb}}$ & $7,3^{\mathrm{c}}$ & $8,4^{\mathrm{d}}$ & 1,33 & 0,042 \\
\hline
\end{tabular}

Tabel 7. Pengaruh interaksi antara fermentor dengan level terhadap berat telur berat yolk kecerahan yolk dan tebal kerabang selama penelitian

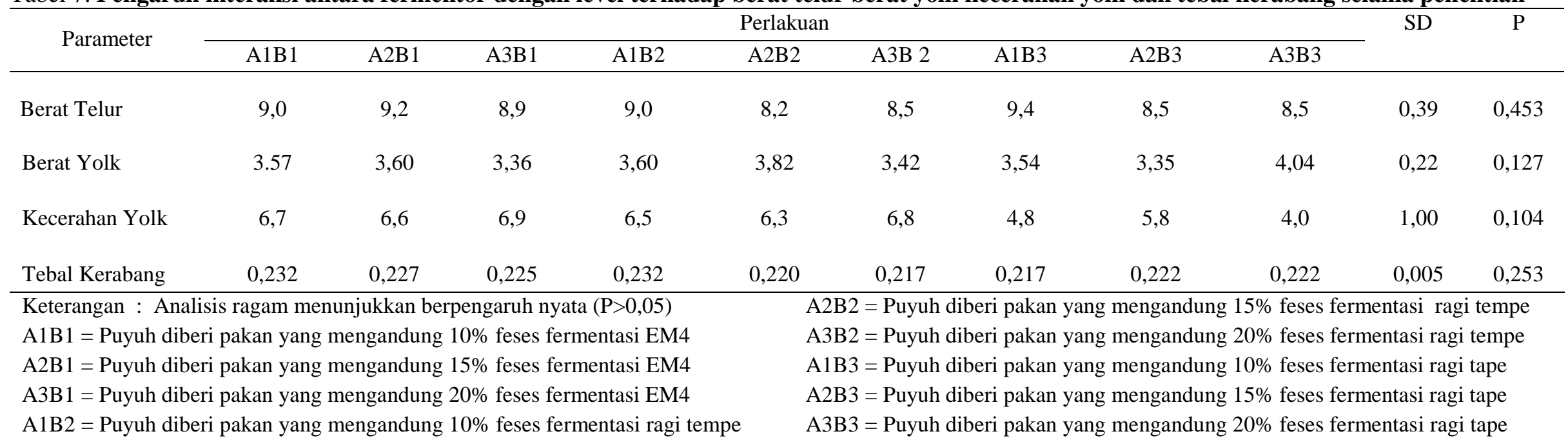


Hasil uji DMRT menujukkan bahwa produksi massa telur terbaik terdapat pada perlakuan A1B1, A2B1 dan A1B2. Produksi massa telur dipengaruhi oleh produksi telur harian dan berat telur, jika salah satu atau kedua faktor semakin tinggi maka produksi massa telur juga semakin meningkat atau sebaliknya.

Hasil uji DMRT memperlihatkan bahwa perlakuan terbaik adalah A1B1, A2B1, A3B1 dan A1B2 hal ini diduga dipengaruhi oleh produksi telur dan konsumsi ransum. Hal ini sesuai dengan penelitian Anggorodi (1994), menyatakan bahwa semakin rendah angka konversi ransum semakin baik karena penggunaan ransum semakin efisien.

\section{b. Interaksi antara fermentor dan level terhadap berat telur, berat yolk, kecerahan yolk dan tebal kerabang}

Hasil sidik ragam (ANOVA) menunjukkan bahwa tipe fermentor bepengaruh tidak nyata terhadap berat yolk, berat telur dan tebal kerabang $(\mathrm{P}>0,05)$ tetapi berpengaruh sangat nyata terhadap kecerahan yolk $(\mathrm{P}<0,01)$. Tabel 7. dapat dijelaskan bahwa penggunaan tipe fermentasi dapat digunakan pada berat telur. Tidak berpengaruhnya tipe fermentor terhadap berat telur diduga mikroba Lactobacillus, Rhizopus oligosporus dan Saccharomyces tidak mampu meningkatkan daya cerna dan mengekresikan enzim protease dan lipase.

Tabel 7 dijelaskan bahwa penggunaan tipe fermentor dapat digunakan pada berat yolk. Tidak berpengaruhnya level pemberian feses fermentasi terhadap berat telur diduga karena mikroba Lactobacillus, Rhizopus oligosporus dan Saccharomyces tidak dapat meningkatkan berat yolk karena penyerapan protein dan lemak dalam proses pembentukan yolk terhambat oleh lendir yang dihasilkan sel goblet di dalam saluran pencernaan.

Hasil uji DMRT menunjukkan bahwa kecerahan yolk pada puyuh yang feses difermentasi dengan ragi tape dan ragi tempe lebih rendah dari EM4 $(\mathrm{P}<0,01)$. Hal ini diduga disebabkan kandungan $B$ karoten yang tinggi pada perlakuan tersebut.

Tabel 7. menjelaskan bahwa penggunaan tipe fermentasi dapat digunakan terhadap tebal kerabang namun tidak memberikan pengaruh level pemberian feses fermentasi terhadap tebal kerabang. Pada penelitian ini jenis dan umur puyuh, jenis pakan, konsumsi pakan, serta penggunaan cahaya penerangan yang digunakan adalah sama sehingga rataan tebal kerabang telur puyuh yang diperoleh berkisar antara 0,220 mm - 0,228 $\mathrm{mm}$ sehingga perlakuan tidak berbeda nyata.

\section{KESIMPULAN}

\section{Kesimpulan}

Pengaruh tipe fermentor yang terbaik untuk memfermentasi feses puyuh adalah EM4. Pengaruh level pemberian feses fermentasi yang terbaik adalah $10 \%$. Interaksi antara tipe fermentor dan level pemberian feses terbaik adalah tipe fermentor EM4 dengan level pemberian feses puyuh sebesar $10 \%$.

\section{DAFTAR PUSTAKA.}

Amrullah, I. K. 2004. Nutrisi Ayam Broiler. Lembaga Satu Gunung Budi IPB. Bogor.

Anggorodi, R. 1994. Ilmu Makanan Ternak Umum . PT Gramedia Utama, Jakarta 
Anonimus. 2007. RI Masih Impor 55 Persen Bahan Baku Obat Hewan. Waspada. Terbit. 14 August 2007.

Astuti, D. A. 2010. Petunjuk Praktis Beternak Ayam Ras, Petelur, Itik dan Burung Puyuh. PT Agromedia Pustaka : Jakarta

Cath, A. U., M. Bozkurt, K. Kucukyilmaz, M. Cinar, E. Bintas, F. Coven and H. Atik. 2012. Performance and egg quality or aged laying hens fed diets supplemented with meat and bone meal or oyster shell meal. South African Journal of Animal Science: 42 (1).

Fenita, Y. I. Badarina, dan E. Tamsar.2005. Uji kerusakan lemak ransum ayam petelur yang menggunakan minyak lemuru (Sardinella longiceps) dengan penambahan bawang putih sebagai antioksidan alami selama penyimpanan. Jurnal Ilmiah Ilmu-Ilmu Peternakan, 8(4) : 45-48

Herni. 2014. Pengaruh ImbanganenergiProtein Terhadap Tebal kerabang Dan Tebal Kerabang Telur Ayam Arab. Skripsi. Fakultas Peternakan. Universitas Hasanudin. Makasar.

Indra Ukrita. 2014. Efisiensi Biaya Ransum Dengan Pemberian Pakan Feses Puyuh Fermentasi Pada Usaha Ternak Sapi. Jurusan Budidaya Tanaman Pangan Politeknik Pertanian Negeri Payakumbuh. Jurnal Embrio, 7(2): 60-66
Kurtini, T., K. Nova., dan D. Septinova. (2014). Produksi Ternak Unggas. Bandar Lampung : Anugrah Utama Raharja (AURA).

Latif., Nuraini dan Sabrina. (2011). Penampilan dan Kualitas Telur Puyuh yang diberi Pakan Mengandung Produk Fermentasi dengan Neurospora crassa. Jurnal Peternakan Indonesia. Fakultas Peternakan Universitas Andalas. Sumbar

Masnun.(Tanpa tahun).Pemanfaatan Limbah Ternak Pelet : Konsentrat Kelinci Feses Puyuh. www.bppjambi.infodwnpublikasi.id. (Diakses Tanggal 18 Januari 2017)

Rasyaf, M. 2006. Beternak Ayam Pedaging. Penebar Swedaya

Santoso,U., F.Nengsih, A.Rozal, J.Setianto and S, Kadarsih. 2004. The effect of fermented feed on growth fat diposition and carcas healthy in broiler chicken. JPPT 29: 27-32

Sihombing, G., Avivah \& S. Prastowo. 2006. Pengaruh penambahan zeolit dalam ransum terhadap kualitas telur burung puyuh. J. Indon. Trop. Anim. Agric. 31(1): 28-31.

Sjofjan, O., Aprilia. F. S. and M. H. Natsir. 2015. Pengaruh penambahan probiotik Lactobacillus plus bentuk tepung sebagai aditif pakan terhadap penampilan produksi burung puyuh. Fakultas Peternakan Universitas Brawijaya, Malang

Yuwanta, T. 2004. Dasar Ternak Unggas. Kanisius, Yogyakarta. 